\title{
Metaplastic Synovial Cyst
}

National Cancer Institute

\section{Source}

National Cancer Institute. Metaplastic Synovial Cyst. NCI Thesaurus. Code C97061.

A cyst lined by tissue that resembles synovial villi. 